Przegląd Prawa Konstytucyjnego

----ISSN 2082-1212-----

DOI 10.15804/ppk.2021.05.37

-----Nr $5(63) / 2021-----$

\title{
Lidia Brodowski ${ }^{1}$
}

\section{Zasada pacta sunt servanda a Konstytucja RP}

Słowa kluczowe: Zasada pacta sunt servanda, prawo międzynarodowe a prawo krajowe, prawo międzynarodowe a konstytucja

Keywords: The principle of pacta sunt servanda, international law and national law, international law and the constitution

\section{Streszczenie}

Artykuł podejmuje problematykę zakresu, roli i miejsca jednej z najważniejszych zasad prawa międzynarodowego zasady pacta sunt servanda w Konstytucji RP. Prezentuje przeciwstawne poglądy przedstawicieli doktryny i stanowisko Autorki w przedmiotowej materii, orzeczenia sądów międzynarodowych i krajowych oraz możliwe rozwiązania ewentualnych kolizji pomiędzy normą prawa wewnętrznego a normą prawa międzynarodowego. Odnosi się także do konsekwencji odmowy wykonania zobowiązania wynikającego z prawa międzynarodowego na skutek przyznania pierwszeństwa i stosowania kolizyjnej w stosunku do niej normy konstytucyjnej oraz kontrowersyjnej na gruncie Konstytucji RP kwestii skuteczności norm prawa zwyczajowego międzynarodowego i zasad ogólnych prawa uznanych przez narody cywilizowane.

1 ORCID ID: 0000-0001-7828-868X, doktor habilitowany, Zakład Prawa Międzynarodowego i Prawa Europejskiego, Instytut Nauk Prawnych, Kolegium Nauk Społecznych, Uniwersytet Rzeszowski. E-mail: lbrodowski@ur.edu.pl. 


\section{Abstract \\ The principle of pacta sunt servanda and the Polish Constitution}

The article deals with the range, role and place of one of the most important principles of international law, the principle of pacta sunt servanda in the Polish Constitution. It presents opposing views of the representatives of the doctrine and the author's position on the subject matter, decisions of international and national courts, and possible solutions to possible collisions between the norm of domestic law and the norm of international law. It also refers to the consequences of refusing to perform an obligation under international law as a result of granting primacy and applying constitutional rule that is contradictory to it and the question of the effectiveness of customary international law norms and general principles of law recognized by civilized nations, which is controversial under the Polish Constitution.

\section{$*$}

\section{I.}

Celem artykułu jest analiza zakresu, roli i miejsca zasady pacta sunt servanda w Konstytucji RP, możliwych rozwiązań ewentualnych kolizji pomiędzy normą prawa wewnętrznego a normą prawa międzynarodowego oraz ewentualnych skutków odmowy wykonania zobowiązania wynikającego z prawa międzynarodowego na skutek przyznania pierwszeństwa i stosowania kolizyjnej w stosunku do niej normy konstytucyjnej.

Zasada pacta sunt servanda zobowiązuje do prawidłowego i rzetelnego wykonywania zobowiązań, wynikających z umów międzynarodowych. Zasada ta obliguje organy władzy publicznej i inne podmioty do podejmowania działań koniecznych dla realizacji postanowień wynikających z zaciągniętych zobowiązań międzynarodowych, a także do zaniechania działań, które byłyby sprzeczne $\mathrm{z}$ tymi zobowiązaniami. Zasada pacta sunt servanda znajduje umocowanie $\mathrm{w}$ jednej $\mathrm{z}$ fundamentalnych zasad prawa międzynarodowego, a mianowicie zasadzie dobrej wiary ${ }^{2}$. Jest uznawana nie tylko za „ogólną za-

2 Zob. Orzeczenie MTS w sprawie testów nuklearnych z 20 grudnia 1974 r., w którym Trybunał uznał że zasada pacta sunt servanda jest oparta na zasadzie dobrej wiary, „International 
sadę prawa uznaną przez narody cywilizowane", ale także normę zwyczajową, potwierdzoną w postanowieniach umów międzynarodowych ${ }^{3}$. Stanowi formalną gwarancję efektywności całego systemu prawa międzynarodowego, wskazując na konieczność wypełniania wynikających $\mathrm{z}$ niego zobowiązań ${ }^{4}$. Jest nie tylko normą prawną ale także normą, która znajduje głębokie uzasadnienie w wartościach moralnych i etycznych ${ }^{5}$.

Zasada pacta sunt servanda znajduje potwierdzenie w treści art. 2 ust. 2 Karty Narodów Zjednoczonych, podpisanej 26 czerwca 1945 r., która stanowi, że: „Wszyscy członkowie, w celu zapewnienia sobie praw i korzyści wynikających z członkostwa, wykonywać będą w dobrej wierze zobowiązania przyjęte przez nich zgodnie z niniejszą Kartą"6. Jej treść precyzuje Deklaracja zasad prawa międzynarodowego dotyczących przyjaznych stosunków i współdziałania państw zgodnie z Kartą NZ, podpisana 24 października 1970 r. w Nowym Jorku , stanowiąc, że: „Każde państwo ma obowiązek wypełniać w dobrej wierze zobowiązania przyjęte przez nie zgodnie z Kartą $\mathrm{NZ}$, oparte na powszechnie uznanych zasadach i regułach prawa międzynarodowego oraz zobowiązania na mocy międzynarodowych porozumień obo-

Court of Justice Reports" (dalej ICJ Reports) 1974, s. 253-274. Szerzej na temat zasady dobrej wiary w prawie międzynarodowym zob. np. M. Kałduński, Zasada dobrej wiary w prawie międzynarodowym, Warszawa 2017 czy E. Lis, Zasada dobrej wiary w prawie międzynarodowym, „Studia Iuridica Lublinensia” 2016, vol. XXV, s. 17-41.

Zob. M. Frankowska, Prawo traktatów, Warszawa 1997, s. 102.

4 R. Kwiecień, Miejsce umów międzynarodowych w porządku prawnym państwa polskiego, Warszawa 2000, s. 41.

5 Zob. np. J.B. Whitton, The Sanctity of Treaties (Pacta Sunt Servanda), „International Conciliation" 1935, vol. 16, s. 395-430; J.L. Kunz, The Meaning and the Range of the Norm Pacta Sunt Servanda, „American Journal of International Law” 1945, vol. 39, No. 2, s. 180- 197; P.W. Gormley, The Codification of Pacta Sunt Servanda by the International Law Commission: the Preservation of Classical Norms of Moral Force and Good Faith, „Saint Louis University Law Journal" 1970, vol. 14, No. 3, s. 367-428; R. Hyland, Pacta Sunt Servanda: a Mediation, „Virginia Journal of International Law” 1994, vol. 34, No. 2, s. 405-433; O.I. Tiunov, Pacta Sunt Servanda: the Principle of Observing International Treaties in the Epoch of the Slave-Owning Society, „Saint Louis University Law Journal” 1994, vol. 38, No. 4, s. 929-945; M. Frankowska, op.cit., s. 101-103; R. Kwiecień, op.cit., s. 40-43.

6 Polska ratyfikowała Kartę 16 października 1945 r. (Dz.U. 1947, Nr 23, poz. 90 ze zm.).

7 Rezolucja Zgromadzenia Ogólnego 2625 (XXV) z 24 października 1970 r., K. Kocot, K. Wolfke, Wybór dokumentów do nauki prawa międzynarodowego, Wrocław-Warszawa 1978, s. 524-533. 
wiązujących w myśl powszechnie uznanych zasad i reguł prawa międzynarodowego" ${ }^{8}$. Swój pełny wyraz zasada pacta sunt servanda znalazła w treści art. 26 Konwencji wiedeńskiej o prawie traktatów z 23 maja 1969 r., zgodnie z którym: „Każdy będący w mocy traktat wiąże jego strony i powinien być przez nie wykonywany w dobrej wierze" 9

II.

Zasada pacta sunt servanda i zasada najwyższej pozycji Konstytucji w hierarchii źródeł prawa nie powinny pozostawać ze sobą w konflikcie. Zgodnie z art. 27 Konwencji wiedeńskiej o prawie traktatów z 23 maja 1969 r.: „Strona nie może powoływać się na postanowienia swojego prawa wewnętrznego dla usprawiedliwienia niewykonywania przez nią traktatu"10. Państwo przed związaniem się treścią umowy międzynarodowej ma więc obowiązek wprowadzenia do swego prawa wewnętrznego takich zmian i uzupełnień, by możliwe było przestrzeganie zobowiązań międzynarodowych ${ }^{11}$. Państwo zawierając umowę międzynarodową, podejmuje wobec innych podmiotów zobowiązania, które - zgodnie z zasadą pacta sunt servanda - musi wykonywać w dobrej wierze. W przypadku gdy przedmiot wspomnianego zobowiązania pozostaje $\mathrm{w}$ sferze regulowanej przez przepisy prawa wewnętrznego, państwo ma obowiązek dostosować przepisy swego prawa do zaciągniętych zobowiązań. Jeśli nie wypełni tego obowiązku - narusza zawartą umowę, narusza zasadę pacta sunt servanda, łamiąc tym samym prawo międzynarodowe ${ }^{12}$ i narażając się na przewidziane prawem międzynarodowym sankcje ${ }^{13}$.

\footnotetext{
8 Por. ibidem, s. 532.

9 Por. tekst Konwencji, A. Przyborowska-Klimczak, Prawo międzynarodowe publiczne. Wybór dokumentów, Lublin 2006, s. 50; Polska ratyfikowała Konwencję 27 kwietna 1990 r. (Dz.U. Nr 74, poz. 439).

10 Por. ibidem, s. 50.

11 Szerzej na ten temat: M. Kałduński, Naruszenie normy krajowej przy wyrażaniu woli związania siętraktatem, „Ruch Prawniczy, Ekonomiczny i Socjologiczny” 2007, z. 2, s. 41-59.

12 M. Frankowska, op.cit., s. 103.

13 Zob. Orzeczenie Trybunału Arbitrażowego z 7 września 1910 r. w sprawie połowów przybrzeżnych na północnym Atlantyku, w którym Trybunał zauważył, że każde państwo ma obowiązek wypełniania swoich zobowiązań w dobrej wierze a konsekwencją ich niewy-
} 
Bezwzględny obowiązek przestrzegania prawa międzynarodowego potwierdza wydana w 1932 r. opinia doradcza Stałego Trybunału Sprawiedliwości Międzynarodowej, w której Trybunał zaprezentował stanowisko, że państwo nie może powołać się wobec drugiego państwa na swoją Konstytucję, po to by uchylić się od obowiązków nałożonych na nie przez prawo międzynarodowe. Działania państwa, sprzeczne z jego zobowiązaniami zaciągniętymi w umowie międzynarodowej, nie stają się legalne przez to, że są zgodne $\mathrm{z}$ jego prawem wewnętrznym. Państwo nie może wobec innych państw zasłonić się przepisami swego prawa wewnętrznego, w tym i konstytucją, gdy narusza umowę międzynarodową ${ }^{14}$. Obowiązek przestrzegania zasady pacta sunt servanda jest mocno utrwalony w orzecznictwie międzynarodowym oraz praktyce państw. Zasada, że państwo nie może powoływać prawa wewnętrznego celem usprawiedliwienia niestosowania prawa międzynarodowego znajduje potwierdzenie w wyroku arbitrażowym z 1872 r. w sprawie statku Alabama, w którym stwierdzono, że Wielka Brytania nie może powoływać się na niedostatki wewnętrznych środków prawnych, aby uchylić się od zobowiązań wynikających z prawa międzynarodowego ${ }^{15}$, wyroku Stałego Trybunału Sprawiedliwości Międzynarodowej z 1923 r. w sprawie statku Wimbledon, w którym Trybunał argumentował, iż teza zakładająca, że decyzja oparta na prawie krajowym usprawiedliwia niewykonanie przyjętych na siebie zobowiązań międzynarodowych jest nie do przyjęcia ${ }^{16}$, wyroku Stałego Trybunału Sprawiedliwości Międzynarodowej z 1926 r. w sprawie interesów niemieckich na Górnym Śląsku, w którym Trybunał zauważył, że prawo wewnętrzne państw z punktu widzenia prawa międzynarodowego jest tylko faktem, objawem woli działalności (praktyki) państw ${ }^{17}$, wyroku Międzynarodowego Trybunału Sprawiedliwości z 1952 r. w sprawie praw obywateli Stanów

konywania są sankcje prawa międzynarodowego, „Reports of International Arbitral Awards” 1910, vol. 11, s. 186.

14 „Permanent Court of International Justice” (dalej PCIJ) 1932, Seria A/B, No. 44, s. 24.

15 J.B. Moore, History and Digest of the International Arbitrations to Which the United States Has Been a Party, Waszyngton 1898, s. 495 i n.; T. Bingham, Alabama Arbitration, Max Planck Encyclopedia of Public International Law, ust. 1-5, Oxford Public International Law: Alabama Arbitration, https://opil.ouplaw.com (18.01.2021); A. Clapham, Brierly's Law of Nations, Oxford 2012, s. 410.

$16 \quad$ PCIJ 1923, Seria A, No. 1, s. 24-26.
$17 \quad$ PCIJ 1926, Seria A, No. 7, s. 17, 22, 42. 
Zjednoczonych w Maroku ${ }^{18}$ czy wyroku Międzynarodowego Trybunału Sprawiedliwości z 1955 r. w sprawie Nottebohma, w którym Trybunał stwierdził, że w płaszczyźnie stosunków międzynarodowych nie będą skuteczne akty prawa wewnętrznego, jeśli będą niezgodne z prawem międzynarodowym ${ }^{19}$.

Obowiązywanie zasady pacta sunt servanda na gruncie polskiego porządku prawnego potwierdza art. 9 Konstytucji Rzeczypospolitej Polskiej z 2 kwietnia 1997 r. ${ }^{20}$, zgodnie z którym „Rzeczypospolita Polska przestrzega wiążącego ją prawa międzynarodowego". Obowiązek przestrzegania wiążącego prawa międzynarodowego posiada status normy ustrojowej ${ }^{21}$. Na mocy wskazanej regulacji Polska wyraziła wolę wykonywania w dobrej wierze zobowiązań międzynarodowych ${ }^{22}$. Z jej treści wynika, że Polska opowiada się za poszanowaniem całego wiążącego ją prawa międzynarodowego, bez względu na formę, w jakiej to prawo występuje i w dobrej wierze wykonuje zobowiązania międzynarodowe ${ }^{23}$. W wyroku z 27 kwietnia 2005 r. Trybunał Konstytucyjny zauważył, że „art. 9 Konstytucji jest nie tylko doniosłą deklaracją wobec społeczności międzynarodowej, ale także zobowiązaniem organów państwa, w tym rządu, parlamentu i sądów do przestrzegania prawa międzynarodowego wiążącego Rzeczpospolitą Polską. Realizacja tego obowiązku wymagać
18 „ICJ Reports” 1952, s. 176.
19 „ICJ Reports” 1955, s. 4 i n.
20 Dz.U. Nr 78, poz. 483 ze zm.

$21 \quad$ Tak np. M. Masternak-Kubiak, Przestrzeganie prawa międzynarodowego $w$ świetle Konstytucji Rzeczypospolitej Polskiej, Kraków 2003, s. 181-182; C. Banasiński, Pozycja prawa międzynarodowego w krajowym porządku prawnym ( $w$ świetle Konstytucji z 1997 r.), „Przegląd Prawa Europejskiego" 1997, nr 2(3), s. 7 czy M. Kruk, Konstytucyjne zasady podstawowe - ich znaczenie prawne i katalog, [w:] Zasady podstawowe polskiej Konstytucji, red. W. Sokolewicz, Warszawa 1998, s. 12.

22 Poprzednie polskie Konstytucje nie wskazywały wyraźnej pozycji norm prawa międzynarodowego w systemie prawa polskiego. Szerzej na ten temat zob. np. S. Rozmaryn, Skuteczność umów międzynarodowych PRL w stosunkach wewnętrznych, „Państwo i Prawo” 1962, nr 12, s. 954-960; K. Skubiszewski, Prawa jednostki, umowy międzynarodowe i porządek prawny PRL, „Państwo i Prawo” 1981, nr 7, s. 12; M. Masternak-Kubiak, Umowa międzynarodowa w prawie konstytucyjnym, Warszawa 1997, s. 127-128; R. Kwiecień, op.cit., s. 94-112; A. Wyrozumska, Umowy międzynarodowe. Teoria i praktyka, Warszawa 2006, s. 538-551.

${ }_{23}$ B. Banaszak, Konstytucja RP a prawo międzynarodowe, [w:] Konstytucja i władza we współczesnym świecie. Doktryna - prawo - praktyka. Prace dedykowane Prof. Wojciechowi Sokolewiczowi na siedemdziesięciolecie urodzin, red. Kruk, J. Trzciński, J. Wawrzyniak, Warszawa 2002, s. 363. 
może - obok stosownych zmian w krajowym porządku prawnym - podejmowania przez organy władzy publicznej, w ramach przypisanych im kompetencji, konkretnych zachowań" ${ }^{24}$. Wskazana norma obliguje więc do wypełniania zobowiązań płynących z prawa międzynarodowego w dwóch płaszczyznach, w płaszczyźnie międzynarodowej wobec innych podmiotów prawa międzynarodowego oraz w płaszczyźnie wewnętrznej. Artykuł 9 Konstytucji RP powinien być interpretowany jako norma prowadząca do wywiązania się z obowiązku międzynarodowoprawnego przy jednoczesnym nienaruszaniu reguł krajowych, a w przypadku gdy jest to niemożliwe nawet przy zastosowaniu obopólnie uzgodnionej wykładni, wówczas wywiązanie się z obowiązku wypływającego ze źródeł prawa międzynarodowego zyskuje pierwszeństwo ${ }^{25}$.

W związku z powyższym trudno zgodzić się z twierdzeniem, że zakres przychylności prawa krajowego wydaje się zawężać regulacja art. 8 ust. 1 Ustawy Zasadniczej stanowiąca, że Konstytucja jest najwyższym prawem Rzeczypospolitej Polskiej. Zdaniem części przedstawicieli doktryny nieuchronnym jest twierdzenie, że w przypadku kolizji normy prawa międzynarodowego z Konstytucją, pierwszeństwo, w świetle prawa krajowego, będzie przysługiwało normie konstytucyjnej ${ }^{26}$.

Celem uniknięcia wskazanej kolizji norm należy doprowadzić do zgodności projektowanych zobowiązań międzynarodowych z Konstytucją RP. Jednym $\mathrm{z}$ instrumentów, które pomagają $\mathrm{w}$ realizacji nakreślonego celu jest przewidziany art. 188 pkt 1 Konstytucji RP mechanizm kontroli zgodności umowy międzynarodowej z Ustawą Zasadniczą, uruchamiany przed Trybunałem Konstytucyjnym przez Prezydenta RP przed planowaną ratyfikacją umowy międzynarodowej (art. 133 ust. 2). Konsekwencją negatywnego orzeczenia Trybunału Konstytucyjnego w tym zakresie (niezgodności umowy międzynarodowej z Konstytucją) jest trzy możliwości, z których pierwsza zakłada odstąpienie od zamiaru ratyfikacji umowy międzynaro-

24 Wyrok TK z 27 kwietnia 2005 r., sygn. P 1/05, „Orzecznictwo Trybunału Konstytucyjnego. Zbiór Urzędowy” 2005, nr 4A, poz. 42.

25 TakA. Kozłowski, Wyrok Trybunału Sprawiedliwości Unii Europejskiej w sprawie niezależności polskich sądów (sprawy połączone C - 585/18 C-624/18, C-625/18) a konstytucyjny wymóg przestrzegania przez Rzeczposoplitą Polską wiążącego ją prawa międzynarodowego-implikacje, „Acta Universitatis Wratislaviensis” Wrocław 2020, No 3978, s. 312-314.

26 Taknp. P. Winczorek, Komentarz do Konstytucji Rzeczpospolitej Polskiej z dnia 2 kwietnia 1997 r., Warszawa 2008, s. 213-214. 
dowej, druga zmianę treści umowy międzynarodowej, tak by była ona zgodna $\mathrm{z}$ Konstytucją, a trzecia zmianę Konstytucji ${ }^{27}$. Możliwa jest także następcza kontrola zgodności wiążącej umowy międzynarodowej z Konstytucją RP, inicjowana na wniosek Prezydenta, Marszałka Sejmu, Marszałka Senatu, Prezesa Rady Ministrów, 50 posłów, 30 senatorów, Pierwszego Prezesa Sądu Najwyższego, Prezesa Naczelnego Sądu Administracyjnego, Prokuratora Generalnego, Prezesa Najwyższej Izby Kontroli lub Rzecznika Praw Obywatelskich (art. 188 i art. 191 ust. 1) $)^{28}$.

Zasada pewności prawa, która jest podstawą każdego demokratycznego systemu prawnego i określenie państwa terminem „państwa prawa”, obliguje do dostosowania treści prawa i jego wykładni do standardów demokratycznego państwa prawa, do których należy „skuteczne kształtowanie przez wiążące Polskę umowy międzynarodowe aktów prawa krajowego"29. Sąd Najwyższy w uzasadnieniu postanowienia Izby Administracyjnej Pracy i Ubezpieczeń Społecznych z 15 czerwca 1993 r. wyraził opinię, że państwo prawa jest to również takie państwo, które dotrzymuje swych zobowiązań ujętych w zawartych przez siebie i prawidłowo ratyfikowanych umowach i konwencjach międzynarodowych, z czego wynika, że normy takich umów i konwencji mogą i powinny być bezpośrednio stosowane w wewnętrznym obrocie prawnym i nie wymagają dla swego stosowania żadnych dodatkowych czynności transformujących. Dotyczy to oczywiście tego rodzaju konwencji, bądź dwustronnych umów, w których, albo, co najmniej w sposób dorozumiany wyrażono zamiar (wolę) stosowania ich w obszarze prawa wewnętrznego, przystępujących do konwencji lub zawierających umowę

27 Konieczność wprowadzenia takiej zmiany w odniesieniu do art. 55 Konstytucji RP, była konsekwencją wprowadzenia europejskiego nakazu aresztowania. Szerzej na ten temat zob. np. L. Brodowski, Problemy konstytucyjne państw członkowskich Unii Europejskiej w związku zeuropejskim nakazem aresztowania, „Zeszyty Naukowe Uniwersytetu Rzeszowskiego”, Seria Prawo, 2013, nr 78, s. 17-33.

28 Kontrola następcza pozwala na usuwanie ewentualnych kolizji pomiędzy zobowiązaniami wynikającymi z umowy międzynarodowej a Konstytucją i eliminację przesłanek odpowiedzialności państwa z tytułu naruszenia prawa międzynarodowego, zob. także M. Wyrozumska, Prawo międzynarodowe oraz prawo UE a konstytucyjny system źródet prawa, [w:] Otwarcie Konstytucji RP na prawo międzynarodowe i procesy integracyjne, red. K. Wójtowicz, Warszawa 2006, s. 73.

29 M. Masternak-Kubiak, Przestrzeganie prawa..., s. 248. 
państw, albo też przyjąć można, iż co najmniej możliwość takiego stosowania wynika $\mathrm{z}$ ich treści lub też $\mathrm{z}$ innych obiektywnych przesłanek towarzyszących ich zawarciu ${ }^{30}$. W dalszej części powołanego uzasadnienia Sąd Najwyższy odwołał się do wskazanego wyżej art. 27 Konwencji Wiedeńskiej o prawie traktatów z 1969 r. ${ }^{31}$

Zgodnie z treścią art. 87 ustęp 1 Konstytucji Rzeczypospolitej Polskiej z 1997 r., źródłami powszechnie obowiązującego prawa, obok ustaw i rozporządzeń, są ratyfikowane umowy międzynarodowe. Umowy są więc jednym $\mathrm{z}$ elementów wewnętrznego porządku prawnego ${ }^{32}$. Mając na uwadze powyższe, posługując się wykładnią a contrario, umów, które nie zostały ratyfikowane, nie można zaliczyć do źródeł prawa wewnętrznego. Umowy takie nie mogą być bezpośrednio stosowane (z uwagi na brak ich ratyfikacji i publikacji w Dzienniku Ustaw) i funkcjonują, jako źródła zewnętrzne, konsekwencją czego jest okoliczność że „(...) do uzyskania skuteczności w prawie krajowym muszą zostać transponowane lub transformowane do prawa krajowego poprzez akty tego prawa"33.

Konstytucja w art. 91 ust. 1 stanowi, że „ratyfikowana umowa międzynarodowa po jej ogłoszeniu w Dzienniku Ustaw Rzeczypospolitej Polskiej, stanowi część krajowego porządku prawnego i jest bezpośrednio stosowana, chyba, że jej stosowanie jest uzależnione od wydania ustawy”. Zgodnie z treścią art. 91 ust. 2, „umowa międzynarodowa ratyfikowana za uprzednią zgodą wyrażoną w ustawie ma pierwszeństwo przed ustawą, jeżeli ustawy tej nie da się pogodzić z umową" ${ }^{34}$. W konsekwencji umowa międzynarodowa ratyfikowana za uprzednią zgodą wyrażoną w ustawie jest w hierarchii

$30 \quad$ I PRN 54/93.

31 L. Wiśniewski, Glosa do postanowienia z 15 czerwca 1993 roku, „Państwo i Prawo” 1994, z. 2, s. 107-110.

32 A. Wasilkowski, Prawo krajowe - prawo wspólnotowe - prawo międzynarodowe. Zagadnienia wstępne, [w:] Prawo międzynarodowe i wspólnotowe w wewnętrznym porządku prawnym, red. M. Kruk, Warszawa 1997, s. 11 i n.; Tenże, Miejsce umów międzynarodowych wedle nowej Konstytucji RP, „Przegląd Legislacyjny” 1997, nr 2, s. 33.

33 Raport przygotowany przez zespół Rady Legislacyjnej pod przewodnictwem A. Wasilkowskiego, Konstytucja RP a prawo międzynarodowe, „Przegląd Legislacyjny” 1997, nr 3, s. 113.

34 Konstytucja Rzeczypospolitej Polskiej. Komentarz, t. I, red. L. Garlicki, Warszawa 1999, s. 5 . 
prawa aktem wyższego rzędu niż ustawa ${ }^{35}$. Art. 90 Konstytucji wprowadza możliwość przekazywania organizacjom lub organom międzynarodowym kompetencji w niektórych sprawach. Z treści wskazanej regulacji wynika, że Konstytucja nie wyznacza w sposób precyzyjny granic dla przekazywania kompetencji na rzecz wskazanych podmiotów. Z art. 90 ust. 1 wynika jedynie pewne ograniczenie o charakterze ilościowym, a mianowicie możliwość przekazania przez państwo kompetencji w „niektórych sprawach”, co implikuje wniosek, że organy państwowe muszą zachować pewien „zasadniczy trzon kompetencji”. W świetle jednoznacznego brzmienia art. 91 ust. 3, prawodawca konstytucyjny dopuszcza przekazywanie organizacjom lub organom międzynarodowym kompetencji prawodawczych ${ }^{36}$. Z treści art. 90 ust. 3 Konstytucji Rzeczypospolitej Polskiej wynika, że prawo stanowione przez organizację międzynarodową, której Polska jest członkiem, jest stosowane bezpośrednio i ma pierwszeństwo w przypadku kolizji z ustawami. Przepis ten gwarantuje skuteczność w prawie wewnętrznym Rzeczypospolitej Polskiej, uchwałom prawotwórczym organizacji międzynarodowych w tym aktom prawa wtórnego, tworzonego w ramach Unii Europejskiej. Źródłem obowiązy wania tego rodzaju norm jest więc umowa międzynarodowa, na mocy której państwa dopuściły możliwość uchwalania obowiązujących je norm, a nie skutek zawarcia tejże umowy w postaci prawa wtórnego organizacji międzynarodowej. Moc wiążąca aktów, do której odnosi się art. 91 ust. 3 Konstytucji, jest konsekwencją wykonywania ratyfikowanej umowy międzynarodowej. Ustawa zasadnicza z 1997 r. nie stanowi wprost, że normy prawa wtórnego są elementem krajowego porządku prawnego, ale do tego rodzaju elementów zalicza umowę, na podstawie której państwo przekazuje na rzecz organizacji międzynarodowej kompetencje stanowienia wiążących norm, można więc uznać, że następstwa wykonywania tej umowy w posta-

35 Wyrok NSA z 29 grudnia 1999 r., I S.A./PO 3057/98.

${ }^{36} \mathrm{~K}$. Wojtyczek, Konstytucyjno - prawne aspekty członkostwa w Unii i Wspólnotach Europejskich, [w: Akcesja do Unii Europejskiej a Konstytucja Rzeczypospolitej Polskiej. XLIII Ogólnopolska Konferencja Katedr i Zakładów Prawa Konstytucyjnego, Polańczyk, 31 maja - 2 czerwca 2001 r., red. H. Zięba-Załucka, M. Kijowski, Rzeszów 2002, s. 98-99. Podobnie: J. Barcz, Akt integracyjny Polski z Unią Europejska w świetle Konstytucji RP, „Państwo i Prawo” 1998, z. 4, s. 8; C. Mik, Przekazanie kompetencji przez Rzeczypospolitą Polska na rzecz Unii Europejskiej (Uwagi na tle art. 90 ust. 1 Konstytucji), [w:] Konstytucja Rzeczypospolitej Polskiej z 1997 roku a członkostwo Polski w Unii Europejskiej, red. C. Mik, Toruń 1999, s. 154 i n. 
ci norm prawa wtórnego, są źródłem powszechnie obowiązującego prawa ${ }^{37}$. Artykuł 91 ust. 3 Konstytucji przyznaje pierwszeństwo bezpośrednio stosowalnemu prawu organizacji międzynarodowej przed ustawą, nie przyznając jednak pierwszeństwa temu prawu przed Konstytucją ${ }^{38}$.

W świetle prawa Unii Europejskiej (UE), prawo to ma pierwszeństwo przed normami prawa krajowego, w tym także przed normą konstytucyjną. W przypadku konfliktu między normą konstytucyjną a normą prawną Unii Europejskiej, organ państwa ma obowiązek pominąć normę konstytucyjną i zastosować normę unijną. Państwo, które odmawia zastosowania normy prawa UE, powołując się na swoją konstytucję, ponosi odpowiedzialność za naruszenie prawa UE. Z drugiej strony - prawo krajowe niemal wszystkich państw członkowskich przyjmuje zasadę nadrzędności konstytucji, która oznacza, że każda stosowana w państwie norma prawna, w tym norma prawa UE, musi być zgodna $\mathrm{z}$ normami zawartymi w konstytucji. W sytuacji wystąpienia konfliktu między normą unijną a normą konstytucyjną organ państwa powinien wykorzystać dostępne procedury konstytucyjności prawa, w celu wyeliminowania normy unijnej z obrotu prawnego ${ }^{39}$.

Zdaniem niektórych przedstawicieli doktryny, przynależność do Unii Europejskiej zmienia miejsce Konstytucji w systemie źródeł prawa. Po pierwsze, następuje ograniczenie zakresu stosowania norm konstytucyjnych określających władcze kompetencje organów państwowych, gdyż w sprawach należących do zakresu działania Unii akty prawotwórcze oraz akty indywidualne są wydawane na zasadach określonych w traktatach założycielskich. Po drugie, pomimo deklarowania zasady nadrzędności Konstytucji, następuje ograniczenie zakresu stosowania norm, które wyznaczają treść działań władzy publicznej. Sądy konstytucyjne nie wydają orzeczeń stwierdzających niekonstytucyjność aktów prawa UE, co prowadzi do wniosku, że konstytucje pozostają najwyższym prawem w państwie tylko w takim zakresie, w jakim państwo członkowskie zachowało swoje kompetencje. Po trzecie, konsekwencją przynależności do Unii Europejskiej jest „swoisty dualizm konstytucyjny”. Traktaty założycielskie regulują organizację i zakres działania Unii stanowiąc swego rodza-

37 M. Masternak-Kubiak, Przestrzeganie prawa..., s. 266-268; A. Kustra, Autonomia prawa wspólnotowego, „Jurysta” 2007, nr 7, s. 11-17.

38 Tak K. Wojtyczek, Konstytucyjno - prawne aspekty..., s. 106.

39 Ibidem, s. 103-107. 
ju „konstytucję europejską”, która wkracza w sprawy zastrzeżone dotychczas dla Konstytucji państw członkowskich, a konstytucje państw członkowskich stanowią konieczne dopełnienie „konstytucji europejskiej”, ponieważ bez odpowiednich postanowień krajowej ustawy zasadniczej nie byłoby możliwe, ani członkostwo w Unii, ani też wykonywanie aktów prawnych wydawanych przez jej organy. Po czwarte, w niektórych państwach ratyfikacja traktatów założycielskich była możliwa dopiero po nowelizacji Konstytucji, w innych natomiast ich ratyfikacja zmieniła znaczenie konstytucji. Konstytucja przestaje więc być „niewzruszalną podstawą i miarą dla wszelkich działań władzy publicznej, a staje się instrumentem integracji europejskiej”. Istotna jest więc odpowiedz na pytanie, czy Konstytucja jest zgodna z treścią umowy międzynarodowej (a nie czy umowa jest zgodna z Konstytucją), a jeżeli nie, to w jakim zakresie wymaga ona zmiany ${ }^{40}$. Tak skonstruowane pytanie jest coraz częściej aktualne ze względu na fakt, że duża liczba umów międzynarodowych dotyczy materii konstytucyjnej (praw człowieka, zasady niedyskryminacji czy rządów prawa). Konstytucja ma zagwarantowane pierwszeństwo w polskim systemie prawnym jeżeli jej przepis nie koliduje z normami prawa międzynarodowego, a w razie kolizji w drodze obopólnie przyjaznej wykładni możliwe jest usunięcie tej sprzeczności. Wystąpienie nieusuwalnej sprzeczności będzie się wiązać de facto z koniecznością zmiany jej postanowień ${ }^{41}$.

\section{III.}

Teza, że zasada pacta sunt servanda jest wiążąca nie tylko w stosunku do umów międzynarodowych czy uchwał prawotwórczych organizacji międzynarodowych (coraz częściej regulujących zagadnienia należące do wewnętrznej kompetencji państwa, które jednocześnie ulegają umiędzynarodowieniu $)^{42}$

40 Ibidem, s. 107; J. Gerkrath, L'emergence d'un droit constitutionnel pour l'Europe, Bruxelles 1997, s. 117 i 277.

${ }^{41}$ J. Podkowik, Zasada nadrzędności Konstytucji a wspólnotowy porządek prawny, [w:] Konstytucja Rzeczypospolitej Polskiej. Próba oceny i podsumowania z perspektywy dziesięciolecia stosowania. Zbiór materiałów z ogólnopolskiej konferencji naukowej, Kraków, 30-31 marca 2007 roku, red. K. Górka, T. Litwin, Kraków 2008, s. 53.

42 Zob.np.J.Menkes, A. Wasilkowski, Organizacje międzynarodowe. Prawo instytucjonalne, Warszawa 2017, s. 128. 
ale również do wszystkich innych zobowiązań międzynarodowych implikuje konieczność odniesienia się do kontrowersyjnej na gruncie Konstytucji RP kwestii skuteczności pozostałych źródeł prawa międzynarodowego, a mianowicie norm prawa zwyczajowego międzynarodowego czy zasad ogólnych prawa uznanych przez narody cywilizowane w polskim porządku prawnym.

Artykuł 87 Konstytucji RP w katalogu źródeł obowiązującego prawa RP wymienia Konstytucję, ustawy, ratyfikowane umowy międzynarodowe, rozporządzenia oraz akty prawa miejscowego, pomijając $\mathrm{w}$ wyliczeniu prawo zwyczajowe międzynarodowe, zasady ogólne prawa uznane przez narody cywilizowane czy uchwały prawotwórcze organizacji międzynarodowych. Mimo rozbieżności opinii wśród przedstawicieli doktryny prawa międzynarodowego i prawa konstytucyjnego dotyczących skuteczności norm prawa zwyczajowego w polskim porządku prawnym, należy przychylić się do stanowiska zgodnie z którym, z uwagi na art. 9 Konstytucji deklarujący przychylność systemowi prawa międzynarodowego, katalog źródeł powszechnie obowiązującego prawa obejmuje poza wymienionymi w art. 87 Konstytucji także inne elementy systemu źródeł prawa międzynarodowego ${ }^{43}$. W postanowieniu Sądu Najwyższego z 13 marca 2008 r. w sprawie z powództwa P. (...) S.A. w K. przeciwko R.E., M.G., A.S., A.B., Skarbowi Państwa Republiki T. o zapłatę, SN zauważył, że art. 87 Konstytucji RP wśród źródeł prawa $\mathrm{w}$ Polsce nie wymienia prawa międzynarodowego, a jedynie ratyfikowane umowy międzynarodowe i nie jest jasne, czy w Polsce źródłem prawa są powszechnie przyjęte zwyczaje międzynarodowe, stanowiące część prawa

43 P. Winczorek wskazuje, że celem członków Komisji Konstytucyjnej Zgromadzenia Narodowego proponujących takie ujęcie przepisu, było uznanie za źródło prawa, obok umów, także zwyczaju międzynarodowego wiążącego Polskę, P. Winczorek, Dyskusja nad podstawowymi zasadami ustroju RP w Komisji Konstytucyjnej Zgromadzenia Narodowego (Dziesięć pierwszych artykułów projektu Konstytucji RP), „Ruch Prawniczy, Ekonomiczny i Socjologiczny” 1995, nr 2, s. 22. Podobne stanowisko prezentują m.in.: K. Działocha, Hierarchia norm konstytucyjnych i jej rola $w$ rozstrzyganiu kolizji norm, [w:] Charakter i struktura norm konstytucji, red.J. Trzciński, Warszawa 1997, s. 78; K. Wójtowicz, Prawo międzynarodowe w systemie źródet prawa RP, [w:] System źródet prawa w Konstytucji Rzeczypospolitej Polskiej. Materiaty XLII Ogólnopolskiej Konferencji Katedr i Zakładów Prawa Konstytucyjnego, Nałęczów, 1-3 czerwca 2000, red. M. Granat, Lublin 2000, s. 67-69 czy K. Działocha, Konstytucyjna koncepcja prawa i jego źródet w orzecznictwie Trybunału Konstytucyjnego, [w:] Księga XX - lecia orzecznictwa Trybunału Konstytucyjnego, red. M. Zubik, Warszawa 2006, s. 314. 
międzynarodowego. Skonstatował jednak, że na gruncie art. 9 Konstytucji RP, można uznać, że źródłem immunitetu jurysdykcyjnego państwa obcego i jego organów w sprawach dotyczących działalności władczej państwa, jest powszechnie stosowany zwyczaj międzynarodowy ${ }^{44}$. W postanowieniu Sądu Najwyższego z 9 maja 2019 r., w sprawie S.P. i Z.P. przeciwko Republice Federalnej Niemiec o odszkodowanie SN zauważył, że obecnie w Polsce jak i w innych państwach, za powszechnie przyjętą zasadę uznaje się, że państwo obce posiada immunitet jurysdykcyjny ${ }^{45}$, wyrażający się niemożnością jego pozywania przed sądami krajowymi w sprawach związanych $\mathrm{z}$ władczą działalnością - acta iure imperii, nie przysługuje on natomiast w sprawach związanych z udziałem w zwykłym obrocie cywilnym i gospodarczym - acta iure gestionis (a źródłem immunitetu jurysdykcyjnego państw obcych wyrażający się niemożnością ich pozywania przed sadami krajowymi jest powszechnie przyjęty zwyczaj międzynarodowy) ${ }^{46}$.

Podobny wiążący status wydają się posiadać zasady ogólne prawa uznane przez narody cywilizowane, co potwierdza nie tylko treść Preambuły Konstytucji, odwołującej się do ogólnoludzkich wartości i potrzeby współpracy ze wszystkimi państwami ${ }^{47}$, ale także konieczność przyjęcia aksjomatu,

$44 \quad$ III CSK 293/07.

45 Szerzej na temat immunitetu jurysdykcyjnego państwa zob. np. R. Sonnefeld, Immunitet jurysdykcyjny państwa: nowe tendencje i otwarte problemy (uwagi na marginesie projektu kodyfikacyjnego KPM-ONZ), „Acta Universitatis Wratislaviensis” 1987, nr 159, s. 152 i n.; J. Sutor, Immunitet państwa, Warszawa 2011, E. Olas, Immunitet jurysdykcyjny państwa w wybranych orzeczeniach sądów krajowych, „Problemy Współczesnego Prawa Międzynarodowego, Europejskiego i Porównawczego" 2012, vol. X, s. 48-62; M. Muszyński, J. Osiejewicz, Immunitet państwa: instytucja na rozdrożu prawa, „Polski Przegląd Stosunków Międzynarodowych” 2013, nr 3, s. 43-70; K.J. Gruszczyński, C.T. Szyjko, Immunitet jurysdykcyjny państwa w prawie międzynarodowym publicznym: aktualne zagadnienia teoretyczno - praktyczne. T II - Wyzwania, wyjątki i tendencje przyznania w XXI w., Warszawa 2014; Ewolucja immunitetów mających swoje źródto w prawie międzynarodowym, red. I. Skomerska-Muchowska, Łódź 2014; H. Fox, F. Webb, The law of state immunity, Oxford 2015; M. Kałduński, Immunitet państwa w prawie międzynarodowym $w$ kontekście zbrodni wojennych i zbrodni przeciwko ludzkości, "Zeszyty prawnicze Biura Analiz Sejmowych Kancelarii Sejmu” 2018, nr 2(58), s. 67-93.

46 II CKS 548/18 Zob. także np. Wyrok SN z 19 czerwca 2018 r. w sprawie z powództwa W.G., H.O., J.G., G.G., A.G. i M.G. przeciwko republice Serbii o zapłatę, I CSK 45/18, OSNC 2019/6/90.

47 M. Masternak-Kubiak, Przestrzeganie prawa..., s. 138. 
że konstytucja państwa demokratycznego musi być oparta na wartościach, uznawanych za fundamentalne dla społeczności międzynarodowej ${ }^{48}$.

\section{IV.}

Konstatując należy podkreślić, że zasada pacta sunt servanda jest zasadą, która ma charakter nie tylko normy prawnej ale znajduje swoje głębokie aksjologiczne uzasadnienie w wartościach etycznych i moralnych. Jest zasadą, która gwarantuje przestrzeganie skutecznie zaciągniętych zobowiązań międzynarodowych i chroni porządek międzynarodowoprawny przed jednostronnymi modyfikacjami opartymi na partykularnych interesach jednego państwa. Zasada pacta sunt servanda znajduje potwierdzenie w normach Konstytucji RP, które obligują do przestrzegania zobowiązań prawnomiędzynarodowych, bez względu na formę w jakiej te zobowiązania występują. Mając na celu realizację obowiązków wynikających z jej treści, Konstytucja wprowadza instrumenty, umożliwiające unikanie bądź eliminowanie kolizji pomiędzy jej regulacjami a zobowiązaniami wynikającymi z prawa międzynarodowego. Deklarowana przez ustawodawcę konstytucyjnego otwartość i przychylność względem prawa międzynarodowego jest realizacją zasady demokratycznego państwa prawnego i gwarantem traktowania Polski, jako równorzędnego podmiotu stosunków międzynarodowych ${ }^{49}$. Obowiązek przestrzegania prawa międzynarodowego powinien stanowić niewzruszalny aksjomat, gwarantujący istnienie i skuteczność tego systemu prawa. Należy jeszcze raz podkreślić, że państwa kształtują swoje międzynarodowe zobowiązania na zasadzie dobrowolności, a w konsekwencji jeżeli państwo podejmuje suwerenną decyzję, by stać się stroną umowy, musi tak ukształtować swój system prawny, by postanowienia tej umowy były przestrzegane. W przypadku wystąpienia kon-

48 Podobnie A. Wasilkowski, Przestrzeganie prawa międzynarodowego, [w:] Otwarcie Konstytucji RP na prawo międzynarodowe i procesy integracyjne, red. K. Wójtowicz, Warszawa 2006, s. 9.

49 Tak również M. Wyrzykowski, Miejsce prawa międzynarodowego w wewnętrznym porządku prawnym (wybrane zagadnienia), [w:] Konstytucja Federalna Szwajcarskiej Konfederacji z 1999 roku i Konstytucja Rzeczypospolitej Polskiej z 1997 roku. Materiaty z polsko - szwajcarskiego sympozjum z 26 i 27 października 2000 roku, red. Z. Czeszejko-Sochacki, Białystok 2001, s. $123-124$. 
fliktu pomiędzy normą prawa wewnętrznego a normą prawa międzynarodowego, państwo powinno wypełnić zobowiązania wynikające z normy prawa międzynarodowego, a swoje prawo wewnętrzne ukształtować zgodnie z zobowiązaniami wynikającymi z prawa międzynarodowego ${ }^{50}$. Odmowa wykonania zobowiązania wynikającego z prawa międzynarodowego na skutek przyznania pierwszeństwa i stosowania kolizyjnej w stosunku do niej normy prawa krajowego (bez względu na jej rangę ${ }^{51}$, destabilizuje porządek międzynarodowo prawny, skutkuje odpowiedzialnością międzynarodową państwa i nieuchronnie prowadzi do zachwiania wiarygodności podmiotu na arenie międzynarodowej.

\section{Literatura}

Banasiński C., Pozycja prawa międzynarodowego w krajowym porzadku prawnym (w świetle Konstytucji z 1997 r.), „Przegląd Prawa Europejskiego” 1997, nr 2(3).

Banaszak B., Konstytucja RP a prawo międzynarodowe, [w:] Konstytucja i władza we wspótczesnym świecie. Doktryna - prawo - praktyka. Prace dedykowane Prof. Wojciechowi Sokolewiczowi na siedemdziesięciolecie urodzin, red. M. Kruk, J. Trzciński, J. Wawrzyniak, Warszawa 2002.

Działocha K., Hierarchia norm konstytucyjnych i jej rola w rozstrzyganiu kolizji norm, [w:] Charakter i struktura norm konstytucji, red. J. Trzciński, Warszawa 1997.

Fox H., Webb F., The law of state immunity, Oxford 2015.

Frankowska M., Prawo traktatów, Warszawa 1997.

Gruszczyński K.J., Szyjko C.T., Immunitet jurysdykcyjny państwa w prawie międzynarodowym publicznym: aktualne zagadnienia teoretyczno - praktyczne. T II - Wyzwania, wyjątki i tendencje przyznania w XXI w., Warszawa 2014.

50 P. Guggenheim, Treite de droit international public, Genewa 1953, s. 31 i n.

51 W tym kontekście niepokój budzą zmiany wprowadzone do Konstytucji Federacji Rosyjskiej przyjętej w ogólnonarodowym referendum 12 grudnia 1993 r. ze zmianami zatwierdzonymi podczas głosowania wszechrosyjskiego 1 lipca 2020 r., w świetle których „Decyzje organów międzynarodowych przyjęte na podstawie umów międzynarodowych, których stroną jest Federacja Rosyjska, o treści sprzecznej z Konstytucją Federacji Rosyjskiej, nie są w Federacji Rosyjskiej wykonywane”. W konsekwencji Federacja Rosyjska wprowadziła prymat prawa krajowego nad prawem międzynarodowym, niezgodny z zobowiązaniami międzynarodowymi. Por. art. 79 Konstytucji Federacji Rosyjskiej, Konstytucja Federacji Rosyjskiej - Ambasada Rosji w Polsce, https://www.mid.ru/ru/home (12. 03. 2021). 
Hyland R., Pacta Sunt Servanda: a Mediation, „Virginia Journal of International Law” 1994, vol. 34, No. 2.

Kałduński M., Immunitet państwa w prawie międzynarodowym w kontekście zbrodni wojennych i zbrodni przeciwko ludzkości, „Zeszyty Prawnicze Biura Analiz Sejmowych Kancelarii Sejmu" 2018, nr 2(58).

Kałduński M., Zasada dobrej wiary w prawie międzynarodowym, Warszawa 2017.

Konstytucja Federalna Szwajcarskiej Konfederacji z 1999 roku i Konstytucja Rzeczypospolitej Polskiej z 1997 roku. Materiały z polsko-szwajcarskiego sympozjum z 26 i 27 października 2000 roku, red. Z. Czeszejko-Sochacki, Białystok 2001.

Konstytucja Rzeczypospolitej Polskiej. Komentarz, t. I, red. L. Garlicki, Warszawa 1999. Kozłowski A., Wyrok Trybunału Sprawiedliwości Unii Europejskiej w sprawie niezależności polskich sądów (sprawy połaczone C - 585/18 C-624/18, C-625/18) a konstytucyjny wymóg przestrzegania przez Rzeczposoplitą Polską wiążącego ją prawa międzynarodowego - implikacje, „Acta Universitatis Wratislaviensis”, t. 3978, Wrocław 2020.

Kruk M., Konstytucyjne zasady podstawowe - ich znaczenie prawne i katalog, [w:] Zasady podstawowe polskiej Konstytucji, red. W. Sokolewicz, Warszawa 1998.

Ksiega XX-lecia orzecznictwa Trybunału Konstytucyjnego, red. M. Zubik, Warszawa 2006. Kunz J.L., The Meaning and the Range of the Norm Pacta Sunt Servanda, „American Journal of International Law" 1945, vol. 39, No. 2.

Kwiecień R., Miejsce umów międzynarodowych w porządku prawnym państwa polskiego, Warszawa 2000.

Lis E., Zasada dobrej wiary w prawie międzynarodowym, „Studia Iuridica Lublinensia” 2016, vol. XXV.

Masternak-Kubiak M., Przestrzeganie prawa międzynarodowego w świetle Konstytucji Rzeczypospolitej Polskiej, Kraków 2003.

Muszyński M., Osiejewicz J., Immunitet państwa: instytucja na rozdrożu prawa, „Polski Przegląd Stosunków Międzynarodowych” 2013, nr 3.

Olas E., Immunitet jurysdykcyjny państwa w wybranych orzeczeniach sądów krajowych, „Problemy Współczesnego Prawa Międzynarodowego, Europejskiego i Porównawczego" 2012, vol. X.

Otwarcie Konstytucji RP na prawo międzynarodowe i procesy integracyjne, red. K. Wójtowicz, Warszawa 2006.

Wasilkowski A., Przestrzeganie prawa międzynarodowego, [w:] Otwarcie Konstytucji RP na prawo międzynarodowe i procesy integracyjne, red. K. Wójtowicz, Warszawa 2006.

Whitton J.B., The Sanctity of Treaties (Pacta Sunt Servanda), „International Conciliation" 1935, vol. 16.

Winczorek P., Komentarz do Konstytucji Rzeczpospolitej Polskiej z dnia 2 kwietnia 1997 r., Warszawa 2008. 
Wyrozumska M., Prawo międzynarodowe oraz prawo UE a konstytucyjny system źródet prawa, [w:] Otwarcie Konstytucji RP na prawo międzynarodowe i procesy integracyjne, red. K. Wójtowicz, Warszawa 2006. 